How to cite this article:

Authors: Marcin Sobiegraj, Piotr Sikora, Andrzej Zaborski

Title of article: „Computer-aided preparation of detail production on numerically controlled lathes”

Mechanik, No. 8-9 (2019)

DOI: https://doi.org/10.17814/mechanik.2019.8-9.76

\title{
Computer-aided preparation of detail production on numerically controlled lathes
}

\author{
MARCIN SOBIEGRAJ \\ PIOTR SIKORA \\ ANDRZEJ ZABORSKI *
}

Mgr inż. Marcin Sobiegraj, msobiegraj@wimii.pcz.pl, https://orcid.org/0000-0001-8276-9275 - Politechnika Częstochowska, Instytut Technologii Mechanicznych, Częstochowa, Polska

Mgr Piotr Sikora, psikora@wimii.pcz.pl, https://orcid.org/0000-0001-5904-6108 - Politechnika Częstochowska, Instytut Technologii Mechanicznych, Częstochowa, Polska

Dr hab. inż. Andrzej Zaborski, prof. PCz, zaborski@itm.pcz.pl, https://orcid.org/0000-0003-1738-5034 - Politechnika Częstochowska Instytut Technologii Mechanicznych, Częstochowa, Polska

The study presents the possibility of using modern CAD/CAM systems for computer simulation of the process of making the detail on a numerically controlled lathe MIYANO BNA 42GTY. The Alkard CNC Wizard software was used. To verify the correctness of the implemented production process, a coordinate measuring machine Zeiss Prismo 5 with a Renishaw PH-20 head was used. The measurements were carried out using the Modus control software.

KEYWORDS: computer-aided production preparation, CAD/CAM systems

\section{Introduction}

Nowadays, production preparation processes in the machine industry are increasingly implemented using advanced CAD and CAD/CAM systems [2, 7]. This applies to both the design and construction stage of product preparation and computer-aided manufacturing [4-6]. At the stage of computer-aided production preparation, CAD/CAM systems are used, which enables a computer generated NC control code for a selected machine tool and selection of appropriate machining parameters $[1,3]$. Machine tool manufacturers are also launching programs for specific machines - an example is the Alkard CNC Wizard program presented in the paper [9]. This software allows for technological preparation of workpiece detail - from the choice of machine tool, through the development of individual technological stages of machining, to the selection of optimal tools and machining parameters. The paper also discusses the possibility of using modern computer software at the stage of verifying the correctness of the production of details obtained using coordinate measuring machines.

The Modus control program allows to define the measurement plan and characteristics of the measured dimensions based on the loaded CAD model of the measured element [10]. This means that the preparation of the measurement using the learning method (manual indication of the planned measurement course) is replaced by computer definition of the measurement strategy.

\section{Preparation of the machining process using a computer}

The starting point for computer-aided preparation of the manufacturing process is development of the CAD model implemented for the production of an element. In the presented example, this element is a detail made of 316L steel. Solid model of the detail, prepared in the SolidWorks program, and the actual detail obtained as a result of the machining process is shown in fig. 1.

The Alkard CNC Wizard is intended for MIYANO automatic lathes. It enables the preparation of the control program without the need to start the machine or stop it (e.g. at the stage of production of another element). The developed program is verified for correct operation, which minimizes the risk of errors that may cause a collision on the machine. 
a)

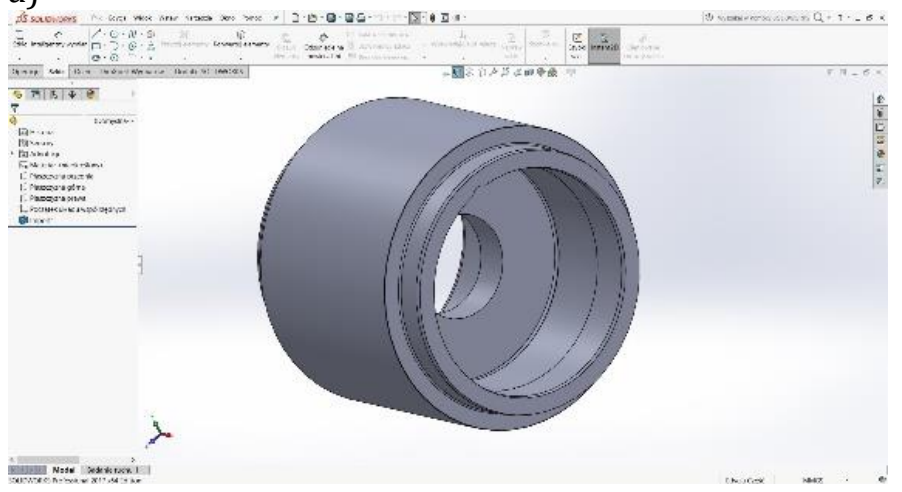

b)

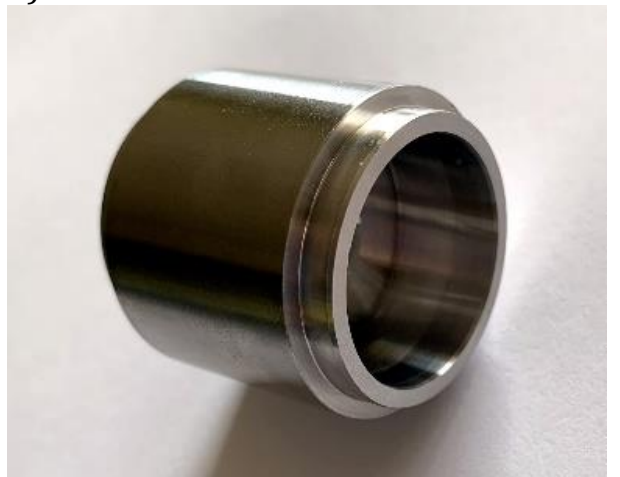

Fig. 1. Virtual model (a) and real detail obtained as a result of machining (b)

Work in the program should start with the choice of the machine (in this case, the MIYANO BNA GTY machine was selected). The subsequent stage is the selection of tool holders. In the next steps, however, provide data on the workpiece output - its outer diameter and length. This information is necessary for the proper functioning of the machine and to eliminate the possibility of collisions.

The MIYANO BNA 42GTY machine tool has a capturing spindle that allows the workpiece to be machined in two clampings. It is therefore necessary to specify the length of the element in the collet of the capturing spindle and anticipated value of the planning allowance on each side of the element. The next tabs of the program, define technological data and parameters, such as:

- the element cutting off feedrate value,

- position in which the cutter is located,

- grip size,

- location of termination of the cutting off procedure.

- spindle rotational speed,

- cutting speed.

After entering necessary data, one can proceed to the development of the control program (fig. 2).

The control program is prepared in three parallel channels, enabling development of individual machining operations (fig. 3). The sample element made of 316L stainless steel presented in the paper has an axis-symmetrical structure. Its production in the shortest possible time requires the simultaneous use of tools that perform machining operations in parallel. For example, in parallel to the operations carried out on the main spindle, roughing and finishing boring operations will be carried out on the intercepting spindle. During the machining of the detail in the described operation on the main spindle, the following technological operations were performed:

- turning the element to the desired dimension from the starting material, which was a drawn rod, in class h9;

- turning the element flange (accuracy up to $0.02 \mathrm{~mm}$ );

- drilling a hole with a solid carbide 3D drill, dimension $\varnothing 11$.

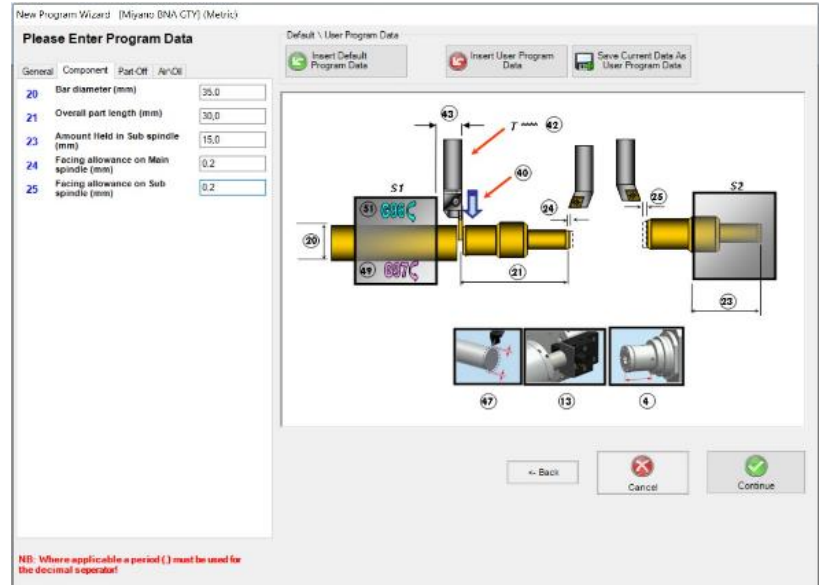

Fig. 2. Defining the control program - "New Program Wizard" dialog box

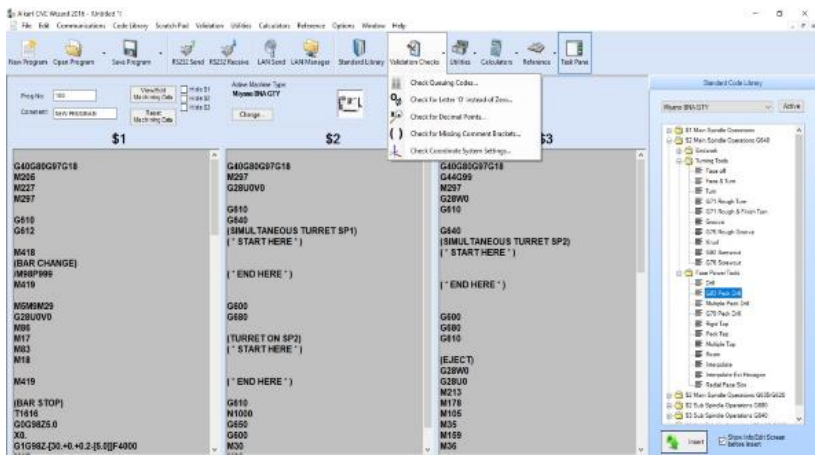

Fig. 3. Preview and computer verification of the prepared three-channel OSN control program 
These operations are followed by preparation for capturing the part, including the arrival of the capturing spindle and capturing the part. Then the workpiece is cut off using the cutter knife. After the counter spindle has moved to the home position, workpiece processing continues. Subsequent operations - roughing and finishing boring of the hole - are carried out simultaneously on the support spindle.

An example of computer-aided definition of a boring operation is shown in fig. 4 .

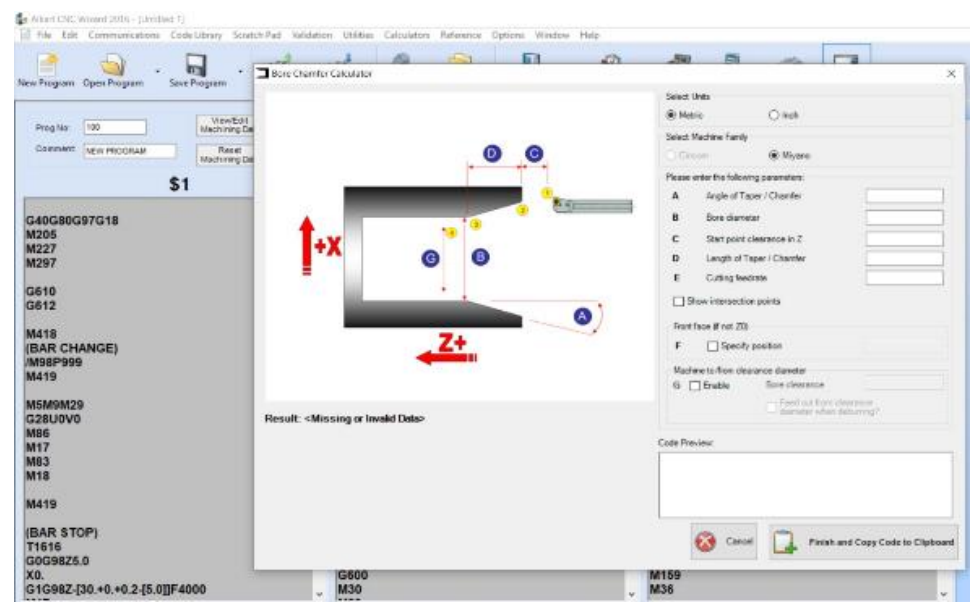

Fig. 4. Defining the parameters for boring the hole for OSN

Presented detail is technologically difficult to make due to the material and performance requirements, allowing small values of the runout of the surface obtained on the main spindle in relation to the surfaces obtained on the capturing spindle (permissible value - up to $0.05 \mathrm{~mm}$ ). It is also difficult to maintain the allowable tolerance of the hole diameter (up to $0.03 \mathrm{~mm}$ ). General roughness of the detail made cannot exceed the level of $R z$ $=10 \mu \mathrm{m}$, and in the hole it is limited to the value of $R z=6.3 \mu \mathrm{m}$.

\section{Implementation of a verified machining process on a longitudinal automaton}

Machining process, realized and verified virtually in the Alkard CNC Wizard [9], has been implemented on a real machine tool and implemented into production. A numerically controlled automatic lathe MIYANO BNA 42GTY [8] equipped with the Mitsubishi control system, was used (fig. 5). This machine is on the equipment of APJ Sikora in Częstochowa, which deals with precise machining.

a)

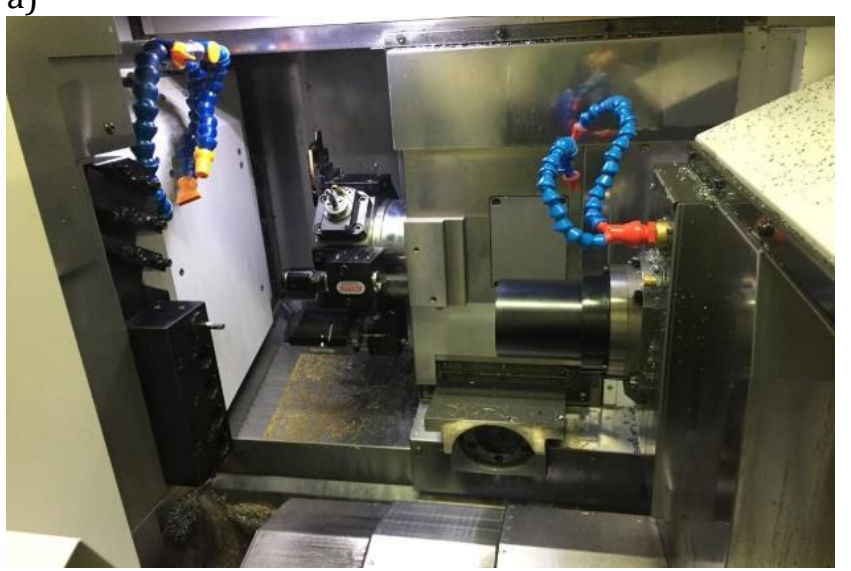

b)

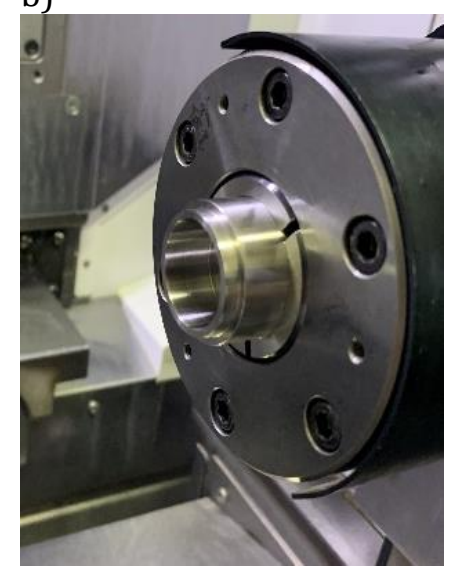

Fig. 5. View of the working space in the machine (a) with the workpiece (b)

\section{Verification of workpiece accuracy on a coordinate measuring machine}

The correctness of workmanship was verified on a Zeiss Prismo 5 coordinate measuring machine equipped with a Renishaw PH-20 measuring head with measuring accuracy up to $0.002 \mathrm{~mm}$. The measurement can be carried out both in the manual control mode of the machine and in the computer-aided mode of preparing the measurement plan based on the Modus program. 
Under conditions of planned serial production of the product, it was decided to prepare a program to control the measurement process. The program includes the option to download information about dimensions and tolerances directly from the CAD model, and its important feature is the offline mode option, which allows for full simulation and collision detection.

The subsequent stage is choosing the right styli, with which one can measure the entire element, and adopting a measurement strategy that depends on the imposed databases in the drawing (fig. 6a). The Renishaw PH20 measuring head works on a contact principle. The software supports the selection of the measurement strategy and the number of measurement points, adapted to the expected measurement accuracy. The highest accuracy is obtained when only the movement of the measuring head is used during the measurement (portal movement introduces additional components of the measurement error). The course of the measurement and an exemplary program for measuring the outer diameter are shown in fig. $6 \mathrm{~b}$.

After conducting defined measurements, one can automatically generate a measurement report containing characteristics of the measured detail.

a)

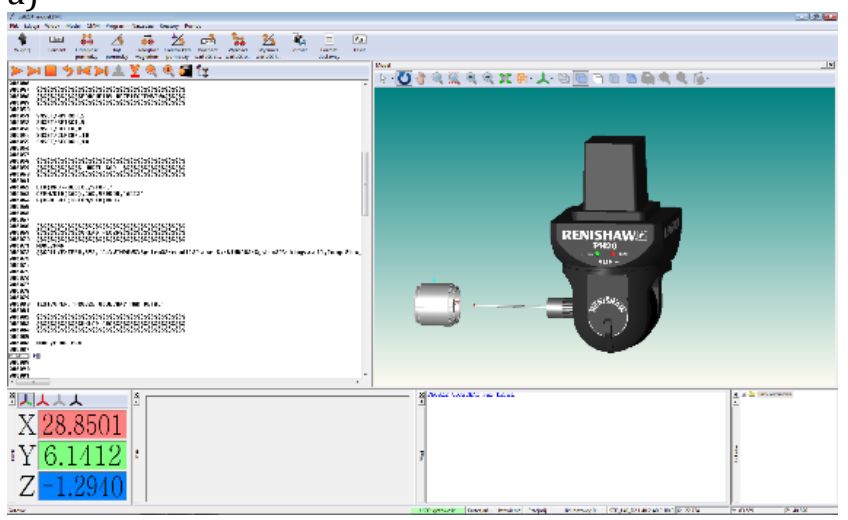

b)

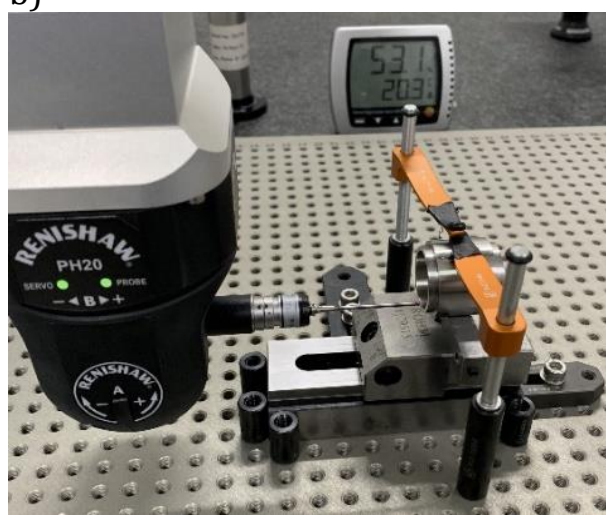

Fig. 6. Defining the stylus (a) and measuring the outer diameter (b)

\section{Summary}

The paper presents possibilities of using the Alkard CNC Wizard program, intended for virtual verification of the technological processing, implemented on the MIYANO BNA 42GTY lathe. The software enabled preparation of the machine control program and elimination of any errors occurring in the NC three-channel control program. The final verification of the correctness of elements implemented for production is ensured by the use of coordinate measuring machines.

\section{REFERENCES}

[1] Grzesik W., Niesłony P., Bartoszuk M. „Programowanie obrabiarek NC/CNC”. Warszawa: Wydawnictwo Naukowo-Techniczne, 2010.

[2] „Podstawy SolidWorks”. Waltham, USA, Dassault Systemes SolidWorks Corporation.

[3] Sikora P., Sobiegraj M., Zaborski A. „Komputerowa weryfikacja cyklu produkcyjnego realizowanego na automacie wzdłużnym". Mechanik. 7 (2018): 558-560.

[4] Tagowski M., Zaborski A. „Przygotowanie produkcji wyrobów przy zastosowaniu systemów CAD i CAD/CAM". Mechanik. 7 (2015): 568/849-856.

[5] Tagowski M., Zaborski A. „Przygotowanie produkcji wyrobów na OSN przy zastosowaniu systemów CAD/CAM". Mechanik. 7 (2016): 846-847.

[6] Tagowski M., Zaborski A. „Komputerowo wspomagane przygotowanie wykonania oprzyrządowania technologicznego przy wykorzystaniu systemów CAD/CAM". Mechanik. 7 (2017): 578-580.

[7] Zaborski A., Tubielewicz K. „Zastosowanie systemów CAD/CAM do komputerowo wspomaganego przygotowania produkcji”. Mechanik. 8-9 (2004): 588-591.

[8] https://cmj.citizen.co.jp/english/product/miyano/bna-gty.html.

[9] https://www.mtdcnc.com/products/software-products/alkart-cnc-wizard.

[10] https://www.renishaw.pl/pl/modus--10495. 